\title{
Dispersal of entomopathogenic fungi, Metarhizium anisopliae and its synergistic with predatory mite, Phytoseiulus macropilis for controlling Tetranychus urticae
}

Dalia A. Waked ( $\sim$ dr.dalia188@yahoo.com )

Plant Protection Research Institute, Agricultural Research Center, Dokki, Giza, Egypt https://orcid.org/0000-0002-1404-9214

\section{Mohamed Elewea}

Plant Protection Research Institute, Agricultural Research Center, Dokki, Giza, Egypt

Abdel Aziz EINasharty Basha

Plant Protection Department, Agriculture Faculty, Zagazig University

Mohamed Hendawy

Plant Protection Department, Agriculture Faculty, Zagazig University

Galal Shabaan Saleh

Plant Protection Research Institute, Agricultural Research Center, Dokki, Giza, Egypt

\section{Research Article}

Keywords: Dispersal, Loading, Metarhizium anisopliae, Phytoseiulus macropilis, Tetranychus urticae

Posted Date: February 5th, 2021

DOI: https://doi.org/10.21203/rs.3.rs-193652/v1

License: (c) (i) This work is licensed under a Creative Commons Attribution 4.0 International License. Read Full License 


\section{Abstract}

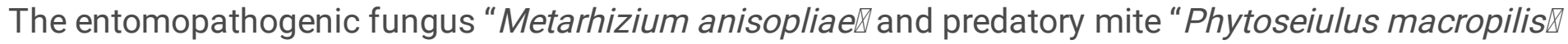
are effective biological controlling agents of Tetranychus urticae. Recent studies have shown that predatory mites, used as biocontrol agents can be loaded with entomopathogenic fungal conidia to increase infection rates in pest populations. It was necessary to study the effect of $M$. anisopliae against $P$. macropilis before executing the experiment. The results showed that the predator mite was more effected by $1 \times 10^{9}$ conidia $/ \mathrm{ml}$ of $M$. anisopliae, while the predator had low effect with $1 \times 10^{6}$ conidia $/ \mathrm{ml}$ of $M$. anisopliae. It was found that the predator had poor effect at indirect spray. Results showed that dispersal of M. anisopliae loaded on P. macropilis delivered high numbers of conidia to T. urticae infested leaves, thereby increased the proportion of $T$. urticae that came into contact with the fungus.

Our study suggests that loading certain predatory mite species with fungal conidia can increase their capacity to suppress thrips populations by combining predation and dispersing pathogens when releasing the loading predatory mite with $M$. anisopliae for controlling $T$. urticae on cucumber crop under greenhouse conditions

\section{Introduction}

Two-spotted spider mite, Tetranychus urticae Koch (Acari: Tetranychidae), is a cosmopolitan and polyphagous species feeding on more than 900 plants including field crops, horticultural crops and ornamental plants, with great economic importance for crops in greenhouses and in the field (Janssen et al. 1997; Zhang 2003; Kumar et al. 2010; Clotuche et al. 2011). Phytophagous mite, Tetranychus urticae Koch as a global agricultural pest, is economically important because it causes high and very quick damaging population levels for host plant due to its rapid developmental rate and high reproductive potential when its growth conditions are good (Van de Vrie, 1972; Meyer, 1996, Navajas, 1998; Nauen et al., 2001; Farouk and Osman, 2011 and Kanika, 2014). Fungal pathogens used as biocontrol agents, now are accepted and have become important as one of the biological controlling components in the IPM programs. (Nugroho and Bin Ibrahim 2004) indicated potential importance of the two entomopathogenic fungi Beauvaria bassiana and Metarhizium anisopliae against mite adults. M. anisopliae has shown higher activity and rapid mortality against mite adults. (Hughes et al. 2004). The entomopathogens play an important role in the regulation of phytophagous mite populations and sometimes to decimate it (Van der Geest et al, 2000). Many predaceous Phytoseiid mites are now used as biological controlling agents in various agricultural ecosystems, and are important predators of phytophagous mite populations in IPM programs on outdoor and greenhouse crops. Phytoseiulus macropilis is one of the most important generalist indigenous predators of tetranychid mites and is widely found on various crops and it is considered one of the main predatory mite used in IPM in Egypt. Pathogens have evolved several ways to disperse and increase the probability of encountering their host. A pathogen can be transferred directly from an infected individual to an uninfected one, indirectly when the host encounters the free-living infectious stage of the pathogen in the environment. A number of studies has shown that arthropods can act as dispersal agents and transmit pathogens passively to potential hosts without becoming 
themselves infected. Arthropod vectors therefore have the potential to shape direct and indirect interactions between a microorganism and its host and consequently, influence their population dynamics, as well as the structure and stability of communities. Hence, biological control may offer a reliable controlling method compatible with other components of an integrated pest management (IPM) programme (Jacobson et al. 2001). Predatory mites should be closely associated to the target pest and have the ability to search for, locate and engage in interactions with the pest on the plant, so they can disperse spores on the plant. In this study, the dispersal and the compatibility of Metarhizium anisopliae with Phytoseiulus macropilis for the management of Tetranychus urticae has been evaluated.

\section{Materials And Methods}

\section{Rearing technique of mite Tetranychus urticae}

Samples of eggplant leaves infested by, Tetranychus urticae. All samples placed in paper bags and transferred immediately to the laboratory. The mass culture was initiated by transferred individuals of females and males using a camel's hair brush placed in petri-dishes $10 \mathrm{~cm}$. diameter, which provided with untreated fresh leaves discs of mulberry (Morus alba L.), about $2.4 \mathrm{~cm}$. diameter placed on a pad of cotton wool fully saturated with water as a source of moisture and to prevent mite escaping. Newly laid eggs and hatched larvae were placed on fresh leaf discs in prepared petri-dishes as mentioned above. The old leaf discs were removed wherever, it was necessary. All colonies were kept in an incubator at $27 \pm 2^{\circ} \mathrm{C}$ and $65 \pm 5 \mathrm{R} . \mathrm{H}$.

\section{Rearing technique of predaceous mite, Phytoseiulus macropilis:}

Predaceous mite was reared on the kidney bean leaves highly infested with $T$. urticae as prey that putted in large metal box $35 \times 25 \times 5 \mathrm{~cm}$, pieces of sponge, $2 \mathrm{~cm}$ thick were put in the middle of each box, putted filter paper on sponge and leaving a space provided with water as a barrier to prevent predatory mites from escaping. T. urticae individuals provided every day as food source. The boxes were kept in an incubator at $27 \pm 2^{\circ} \mathrm{C}$ and $65 \pm 5 \%$ R.H. water was added daily to maintain suitable moisture for the predator rearing.

\section{Fungus culture:}

The fungus $M$. anisopliae was isolated from the soil. Virulence of fungus against $T$. urticae was studied and maintained on sabouraud dextrose agar (SDA). SDA media (Glucose $=4.0 \%$, Mycological peptone $=$ $1 \%$ and Agar $=1.5 \%$ ) was autoclaved for 20 minutes at $121^{\circ} \mathrm{C}$ and then poured on to sterilized petridishes separately (Alves et al., 1998). Left for $24 \mathrm{hr}$.in air flow to cool down, and then incubated at $25 \pm 2{ }^{\circ} \mathrm{C}$ and $80 \pm 5 \%$ R.H. spore production was observed after 2 weeks of fungal culturing.

Efficiency evaluation of the entomopathogenic fungus, $M$. anisopliae on some biological aspects of $P$. macropilis. 
Thirty-five adult females from the predator were reared individually, placed on clean mulberry leaf discs upper side down on moist cell cotton in petri- dishes and sprayed with two concentrations $1 \times 10^{6}$ and $1 \times 10^{9} \mathrm{conidia} / \mathrm{ml}$ of $M$. anisopliae (Direct spray). The treated predator females with M. anisopliae were fed on all stages of $T$. urticae, that added to each arena daily to ensure an abundance of food. Treatment (Indirect spray) contained adult females from T. urticae were sprayed with $1 \times 10^{6}$ and $1 \times 10^{9}$ conidia/ml of $M$. anisopliae by a glass manual atomizer. After $24 \mathrm{hr}$, one starved female of $P$. macropilis was added with known number of treated T. urticae females. The petri-dishes were incubated under constant temperature $27 \pm 2^{\circ} \mathrm{C}$ and R.H approximately $65 \%$. The control check discs were treated with sterile water mixed with a wetting agent (tween 80 ). Longevity, fecundity, egg fertility and consumption for survived predator individuals for the treated and untreated females (control) were calculated.

\section{Dispersal of fungus, $M$. anisopliae:}

Plastic pots were planted with kidney bean and when it reached 20 days old, known number from $T$. urticae has been put on leaf of plant at position (2) after that put Eppendorf with loaded predator (which treated with $1 \times 10^{6}$ conidia / $\mathrm{ml}$ of $M$. anisoplias on the stem of plant, position (A). Recording $M$. anisopliae on plant and prey, T. urticae. To detect the presence or absence of M. anisopliae on living $T$. urticae that remained on plants until the end of the experiment, T. urticae were individually picked with a sterilized toothpick or clean fine brush (sterilized with $90 \%$ ethanol and rinsed with $0.1 \%$ Tween-80 between samples) and placed in a small Petri dish $(\varnothing 3.5 \mathrm{~cm})$ containing $2.5 \mathrm{ml}$ of selective media for $M$. anisopliae. Petri dishes were examined 10 days later when colony-forming units (CFUs) can be visualized. The proportion of $T$. urticae bearing conidia was calculated. To assess the number of conidia on each plant part following arthropod removal, leaves and stems were cut into small pieces $(<2 \mathrm{~cm}$ in width or length) and put back into the solo cup. Conidia were washed off by adding $5 \mathrm{ml}$ of $0.1 \%$ Tween- 80 into each solo cup and the cups were put on a rotary shaker for 2 hours at a speed of $125 \mathrm{rpm}$. Next, one aliquot of a $0.5 \mathrm{ml}$ suspension was transferred onto the selective media for $M$. anisopliae and CFUs were counted 9 days later.

\section{Release of loaded $P$. macropilis with $M$. anisopliae for synergistic management of $T$. urticae on cucumber crop in greenhouse:}

\section{Prey culture}

The two spotted spider mite, Tetranychus urticae was reared on kidney bean plants, Phaseolus vulgaris L. planted in greenhouse at Sharkia Governorate. When kidney been plants had 20 days old age, were infested with $T$. urticae collected from leaves of eggplant and then individuals of the $T$. urticae mite moved off the infested leaves to the new foliage.

\section{Predators rearing}

After one week from infestation kidney plant the phytoseiid predator mite, P. macropilis was reared on kidney bean plants, Phaseolus vulgaris L. planted in 
greenhouse at Sharkia Governorate. Excised bean leaves highly infested with $T$. urticae were provided every other day as food source.

\section{Sowing practices}

The experimental area (greenhouse) was $\left(9 \times 45 \mathrm{~m}^{2}\right)$ planted with cucumber seeds that were divided into 3 plots representing the different treatments, (releasing loaded predator with $M$. anisopliae, unloaded predator and control) each plot (about $9 \mathrm{~m}^{2}$ ). Seeds were sown in hills bads, on one side of the ridge of $80 \mathrm{~cm}$ in width. The different treatments were applied after three weeks from complete germination. Treatments were arranged in plots each design with three replicates (each replicate contains 25 plants).

\section{Releasing of the predatory mite; $P$. macropilis}

Releasing of the predatory mite was carried out in greenhouse planted with cucumber plants. The treatments were releasing loaded predator at $1 \times 10^{6}$ conidia / $\mathrm{ml}$ of $M$. anisopliae, unloaded predator and control with ratio, 1:10 predator: prey T. urticae, respectively. Each treatment was represented by 3 replicates each about $3 \times 3 \mathrm{~m}^{2}$. A plastic sheet was fixed between each replicate to avoid the predatory mite escaping to the other one. The required population numbers of predatory mite individuals were calculated according to the following formula:

Released number $=$ Total no. of $T$. urticae in treatment $\times$ Predator ratio $/$ Prey ratio. Bean leaves with the loaded and unloaded predatory mites were transferred in an ice-box to the greenhouse and then distributed on infested cucumber plants with $T$. urticae except the treatment which was kept free from any controlling agents. After one week of releasing, 20 cucumber leaves were investigated to count the movable stages of $T$. urticae and the predatory mite for 10 subsequent weeks. The reduction percentages were calculated using equation of Henderson and Tilton (1955) was also applied.

\section{Statistical analysis}

Data were subjected to statistical analysis using one-way analysis of variance, ANOVA Duncan (1955).

\section{Results And Discussion}

\section{Efficiency evaluation of the entomopathogenic fungus, $M$. anisopliae on some biological aspects of $P$. macropilis.}

Two concentrations, $1 \times 10^{6}$ and $1 \times 10^{9}$ conidia/ml of $M$. anisopliae were used against $P$. macropilis with two treatments, direct and indirect spray. It was noticed that two treatments shortened the longevity and reduced the fecundity of adult females of $P$. macropilis with different percent. Results in table (1) reveal that, the longevity of individuals was 20.53 and 15.42 days at concentration $1 \times 10^{6}$ and $1 \times 10^{9} \mathrm{conidia} / \mathrm{ml}$ on the predator with direct spray, while in indirect spray of predator it was 23.09 and 21.11 days at the same previous concentrations compared with 23.03 days for control. There was no any significant 
difference in the fecundity, between indirect spray and the control, the total number was 35.12 and 32.43 eggs compared with 38.75 eggs for control. The total consumption of T. urticae was near similar in indirect spray with the control 87.26 and 82.19 preys and compared with 95.54 preys. while, the consumption reduced in direct spray. The previous results showed that the predator mite more effected by $1 \times 10^{9}$ conidia/ml of $M$. anisopliae while, the predator had low effect with $1 \times 10^{6}$ conidia $/ \mathrm{ml}$ of $M$. anisopliae. It was found that the predator had poorly effect at indirect spray. Generally, it would be appeared that conjoint usage of tested $M$. anisopliae with predatory mite; P. macropilis in IPM may require applying biological control agents, entomopathogenic fungi and the predator in sequence unseparated by time intervals. Midthassel et al. (2016) reveled that the results from the study the susceptibility of $A$. swirskii as a physiological host for $B$. bassiana is confirmed with slight virulence depending on exposure type.

Table (1). Functional response of $P$. macropilis treated by $M$. anisopliae and its feeding on treated prey

\begin{tabular}{|c|c|c|c|c|c|c|}
\hline \multirow[t]{2}{*}{ Treatments } & \multirow{2}{*}{$\begin{array}{l}\text { Conc. (No. } \\
\text { conidia/ml) }\end{array}$} & \multirow[t]{2}{*}{ Longevity } & \multirow[t]{2}{*}{ Fecundity } & \multirow{2}{*}{$\begin{array}{c}\text { Egg } \\
\text { fertility } \\
\%\end{array}$} & \multicolumn{2}{|c|}{ Consumption } \\
\hline & & & & & $\begin{array}{l}\text { Oviposition } \\
\text { period }\end{array}$ & Total \\
\hline \multirow{2}{*}{$\begin{array}{l}\text { Direct } \\
\text { spray }\end{array}$} & $1 \times 10^{6}$ & $20.53 \pm 0.97^{a}$ & $28.46 \pm 2.26^{b}$ & 96 & $60.18 \pm 3.45$ & $77.37 \pm 4.08^{b}$ \\
\hline & $1 \times 10^{9}$ & $15.42 \pm 0.89^{b}$ & $21.37 \pm 1.72^{\mathrm{C}}$ & 95 & $27.57 \pm 1.87$ & $53.28 \pm 3.52^{\mathrm{C}}$ \\
\hline \multirow{2}{*}{$\begin{array}{c}\text { Indirect } \\
\text { spray }\end{array}$} & $1 \times 10^{6}$ & $23.09 \pm 1.34^{\mathrm{a}}$ & $35.12 \pm 2.87^{a}$ & 98 & $75.62 \pm 4.08$ & $87.26 \pm 4.76^{\mathrm{a}}$ \\
\hline & $1 \times 10^{9}$ & $21.11 \pm 1.02^{\mathrm{a}}$ & $32.43 \pm 2.64^{\mathrm{a}}$ & 97 & $70.15 \pm 4.11$ & $82.19 \pm 4.38^{b}$ \\
\hline Control & & $23.03 \pm 1.52^{\mathrm{a}}$ & $38.75 \pm 2.89^{a}$ & 98 & $81.65 \pm 4.57$ & $95.54 \pm 5.22^{\mathrm{a}}$ \\
\hline
\end{tabular}

Means in column followed by the same letter are not significantly different at $5 \%$ level

(Duncan's 1955 multiple range tests). Indirect spray = Predator feed on treated prey with M. anisopliae

Data in table (2) and fig. (2) show dispersal of loaded predator with M. anisopliae on kidney bean plant and $T$. urticae individuals that exist on the plant after 3,7 and 10 days of releasing the predator on the plant that found number of $M$. anisopliae conidia distributed that fall down from the predator on kidney bean leaves in addition to the conidia reached to the prey, $T$. urticae resulted from the predator feeds and touched the prey. It was found that population of conidia increased with increasing the time after the releasing till reached maximum 23.50 conidia /prey after 10 days of the predator release while it was 13.27 conidia/leaf. These results are in agreement with Gongyu et al. (2019) loaded certain predatory mite, Neoseiulus cucumeris with fungal conidia, Beauveria bassiana can increase their capacity to suppress thrips, Frankliniella occidentalis populations by combining predation and dispersing pathogens.

Table (2). Dispersal of fungus, $M$. anisopliae loaded on $P$. macropilis after 10 days from its release on Kidney bean infested with $T$. urticae 


\begin{tabular}{|c|c|c|}
\hline Days after release the predator & \multicolumn{2}{|c|}{ Number of M. anisopliae conidia } \\
\cline { 2 - 3 } & T. urticae prey & Kidney bean leaf \\
\hline $\mathbf{3}$ & $04.63 \pm 0.02$ & $02.03 \pm 0.03$ \\
\hline $\mathbf{7}$ & $16.43 \pm 0.15$ & $07.15 \pm 0.06$ \\
\hline $\mathbf{1 0}$ & $23.50 \pm 1.03$ & $13.27 \pm 0.09$ \\
\hline
\end{tabular}

Data in table (3) indicate that, the examined cucumber leaves before releasing $P$. macropilis and infestations with the two-spotted spider mite, T. urticae were generally high as its populations at the precount 135, 122 and 152 individual / 20 leaves for loaded predator, unloaded predator and control, respectively. The number of the target pest in treatment as $T$. urticae movable stages was reduced after one week till $9^{\text {th }}$ week after loaded predator release while, the number was reduced after one week till $6^{\text {th }}$ week after unloaded predator release. The reduction percentage in mite count after one week from release was 24.93 and $27.51 \%$ for loaded predator and unloaded predator. Concerning, the reduction percentage of the pest that increased gradually to reach its maximum in the $9^{\text {th }}$ week after loaded predator release as the calculates reduction percentages was $90.72 \%$ and $79.33 \%$ for unloaded predator release at $5^{\text {th }}$ week. It was found significant differences at the mean reduction percentage of loaded predator that was $70.59 \%$ and $59.27 \%$ for unloaded predator. These results are in agreement with El- Naggar et al. (2008) who reported that, the reduction percentage after 10 weeks of release the predatory mites $P$. persimilis at level 1: 10 of treatment was $72.84 \%$ under greenhouse and Heikal and Fawzy (2003) released the predatory mite, $P$. macropilis for controlling the two spotted spider mite, T. urticae in greenhouse that revealed the release of this predator was successful in reducing the population of $T$. urticae.

Table (3). Release of $P$. macropilis on cucumber plants in greenhouse for controlling $T$. urticae 


\begin{tabular}{|c|c|c|c|c|c|c|}
\hline \multirow{2}{*}{\multicolumn{2}{|c|}{ Sampling date }} & \multicolumn{2}{|c|}{ Loaded predator } & \multicolumn{2}{|c|}{ Unloaded predator } & \multirow{2}{*}{$\begin{array}{c}\text { Control } \\
\text { /20 leaves }\end{array}$} \\
\hline & & $\begin{array}{c}\text { NO. } \\
\text { T. urticae } \\
\text { /20 leaves }\end{array}$ & $\mathrm{R} \%$ & $\begin{array}{c}\text { NO. } \\
\text { T. urticae } \\
\text { /20 leaves }\end{array}$ & $\mathrm{R} \%$ & \\
\hline \multicolumn{2}{|l|}{$\begin{array}{l}\text { Pre-count } \\
\text { /20 leaves }\end{array}$} & 135 & - & 122 & & 152 \\
\hline \multirow[t]{10}{*}{ Weeks after releasing } & 1 st & 110 & 24.93 & 96 & 27.51 & 165 \\
\hline & $2^{\text {nd }}$ & 90 & 39.58 & 65 & 45.28 & 148 \\
\hline & $3^{\text {rd }}$ & 53 & 64.89 & 47 & 65.55 & 170 \\
\hline & $4^{\text {th }}$ & 40 & 76.90 & 42 & 73.16 & 195 \\
\hline & $5^{\text {th }}$ & 50 & 73.31 & 35 & 79.33 & 211 \\
\hline & $6^{\text {th }}$ & 39 & 80.48 & 48 & 73.42 & 225 \\
\hline & $7^{\text {th }}$ & 34 & 82.51 & 57 & 67.57 & 219 \\
\hline & $8^{\text {th }}$ & 22 & 87.91 & 66 & 59.88 & 205 \\
\hline & $9^{\text {th }}$ & 14 & 90.72 & 63 & 53.82 & 170 \\
\hline & $10^{\text {th }}$ & 17 & 84.68 & 53 & 47.17 & 125 \\
\hline \multicolumn{2}{|l|}{ Mean R\% } & - & $70.59^{a}$ & - & $59.27^{b}$ & - \\
\hline
\end{tabular}

Means in row followed by the same letter are not significantly different at $5 \%$ level (Duncan's 1955 multiple range tests).

\section{Conclusion}

The fungus $M$. anisopliae and the predatory mite, $P$. macropilis are regarded among of the most important biological control agents of the spider mite, $T$. urticae. It was possible to use both agents together in the control process, where a weak concentration of $M$. anisopliae was used and the predator loaded with it for the possibility of its spread in the infected fields. The results were satisfactory as it was possible to load the predator with M. anisopliae and release it on the cucumber crop in the fight against the spider mite present on the cucumber leaves. Conidia of $M$. anisopliae present on the leaves and $T$. urticae individuals were recorded and counted as a result of the fall of these conidia from the back of the predator during walking and feeding on T. urticae individuals. And the reason for a reduction in the population exceeded $90 \%$ and by a significant increase over the release of the unloaded predator with $M$. anisopliae.

\section{Declarations}

Ethics approval and consent to participate: Not applicable

Consent for publication: Not applicable

Availability of data material: Not applicable 
Competing interests: The authors declare that they have no competing interests

Funding: No funding was obtained for this study All authors read and approved the final manuscript.

Acknowledgements: We would like to acknowledge all members of acarology department in Plant Protection Research Institute, ARC.

\section{References}

Alves, R. T.; R. P. Bateman; C. Prior and S. R. Leather (1998). Effect of simulated solar radiationon conidial germination of Metarhizium anisopliaein different formulations. Crop Prot.,17: 675-679.

Clotuche, G.; A.C. Mailleux; A.A. Ferna'ndez; J.L. Deneubourg and C. Detrain, (2011). The formation of collective silk balls in the spider mite Tetranychus urticae Koch. PLoS ONE, 6(4): 1804-1817

El-Naggar, M.E.; A.M. Metwally; Zakia, E. A. Darwish and Azzia, M. M. Abou Zaid (2008). Biological control of Tetranychus urticae Koch on cucumber plants by using of two predaceous mites, Phytoseiulus persimilis and Neoseiulus californicus under greenhouse condition. Egypt. J. Agric. Res., 86 (1): 269- 279.

Farouk, S. and M.A. Osman, (2011). The effect of plant defence elicitors on common bean (Phaseolus vulgaris L.) growth and yield in absence or presence of spider mite (Tetranychus urticae Koch) infestation. J. Stress Physio. and Biochem.; 7(3): 6-22.

Gongyu L.; C. Guertin; D.P. Sean-Anthony; T. Silvia and B. Jacques (2019). Phytoseiid predatory mites can disperse entomopathogenic fungi to prey patches. Scientific Reports 9:19435 doi.org/10.1038/s41598019-55499-8

Heikal, I.H. and M.M. Fawzy (2003). Apreliminary study of biological control of Tetranychus urticae Koch on cucumber (Acari: Tetranychidae). Egypt. J. Agric. Res., 81 (1): 93 - 100

Henderson, C.F. and E.W. Tilton (1955). Tests with acaricides against the brown white mite. J. Econ. Entomol., 48:157-161.

Hughes, W.O.H.; K.S. Petersen; L.V. Ugelvig; D. Pedersen; L. Tomsen; M. Poulsen and J.J. Boomsma (2004). Density-dependence and within-host competition in a semelparous parasite of leaf-cutting ants. Bio. Med. Central Evoutionary Biology: 4: 45.

Jacobson R.J.; D. Chandler; J. Fenlon and K.M. Russell (2001). Compatibility of Beauveria bassiana (Balsamo) Vuillemin with Amblyseius cucumeris Oudemans (Acarina: Phytoseiidae) to control Frankliniella occidentalis Pergande (Thysanoptera: Thripidae) on cucumber plants. Biocontrol Science and Technology, 11, 391-400

Janssen, A.; J. Bruin; G. Jacobs; R. Schraag and M.W. Sabelis (1997). Predators use volatiles to avoid prey patches with conspecifics. Journal of Animal Ecology, 66: 223-232 
Kanika, T. (2014). A review on reproductive strategies in two spotted spider mite, Tetranychus urticae Koch 1836 (Acari: Tetranychidae) Indian J. of Entom. and Zoo. Studies; 2 (5): 48-52.

Kumar, S.V.; C. Chinniah; C. Muthiah and A. Sadasakthi (2010). Management of two spotted spider mite Tetranychus urticae Koch a serious pest of brinjal, by integrating biorational methods of pest control. Journal of Biopesticides, 3(1): 361-368

Meyer, M. K. P. S. (1996). Mite pests and their predators on cultivated plants in southern Africa. Vegetables and berries. ARC, South Africa.

Midthassel A.; Simon R. Leather; Denis J. Wright and lan H. Baxter (2016). Compatibility of Amblyseius swirskii with Beauveria bassiana: two potentially complimentary biocontrol agents. BioControl. 61:437447

Nauen, R.; N. Stumph; A. Elbert; C.P. Zebitz and W. Kraus (2001). Acaricide toxicity and resistance in larvae of different strains of Tetranychus urticae and Panonychus ulmi (Acari: Tetranychidae). Pest Manag. Sci.; 57: 253-261.

Navajas M. (1998). Host plant associations in the spider mite Tetranychus urticae (Acari: Tetranychidae): insights from molecular phylogeography. Exp. Appl. Acarol.; 22: 201-214.

Van de Vrie, M.; J.A. McMurty and C.B. Huffaker (1972). Ecology of tetranychid mites and their natural enemies: a review. III. Biology, ecology and pest status, and host plant relations of tetranychids. Hilgarida; 41: 343-432.

Van der Geest, L.P.S.; S.L. Elliot; J.A.J. Breeuwer and E.A.M. Beerling (2000). Diseases of mites. Experimental and Applied Acarology, 24: 497-560.

Zhang, Z.Q. (2003). Mites of Greenhouses: Identification, Biology and control. CABI Publishing, Wallingford, UK, xii pp. 244.

\section{Figures}




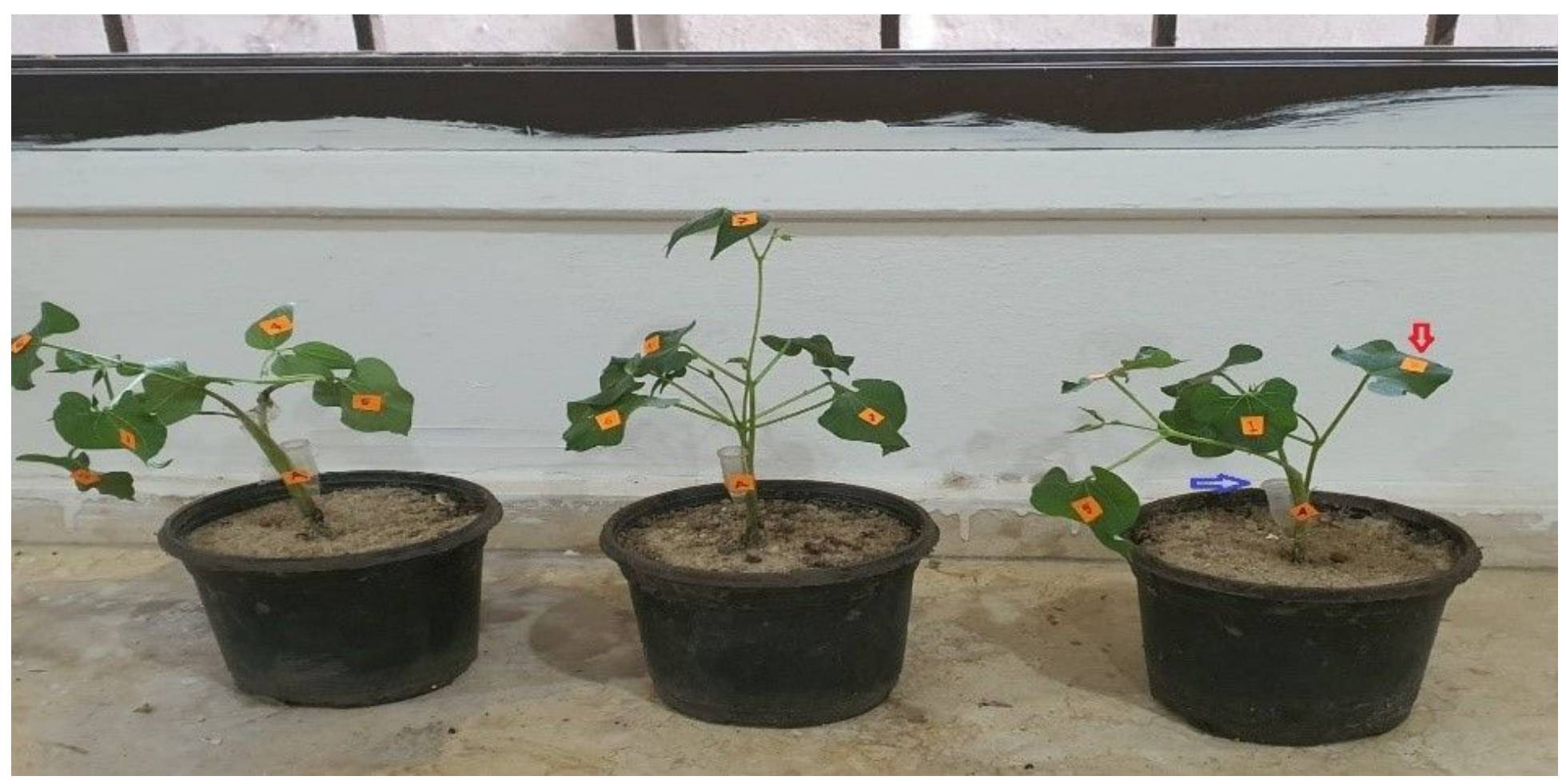

Figure 1

Dispersal of fungus, M. anisopliae loaded on P. macropilis An Eppendorf tube containing predatory mites and fungal conidia to be released was attached on stem in position (A) Distribution of T. urticae on leaflet of kidney bean in position (2) 


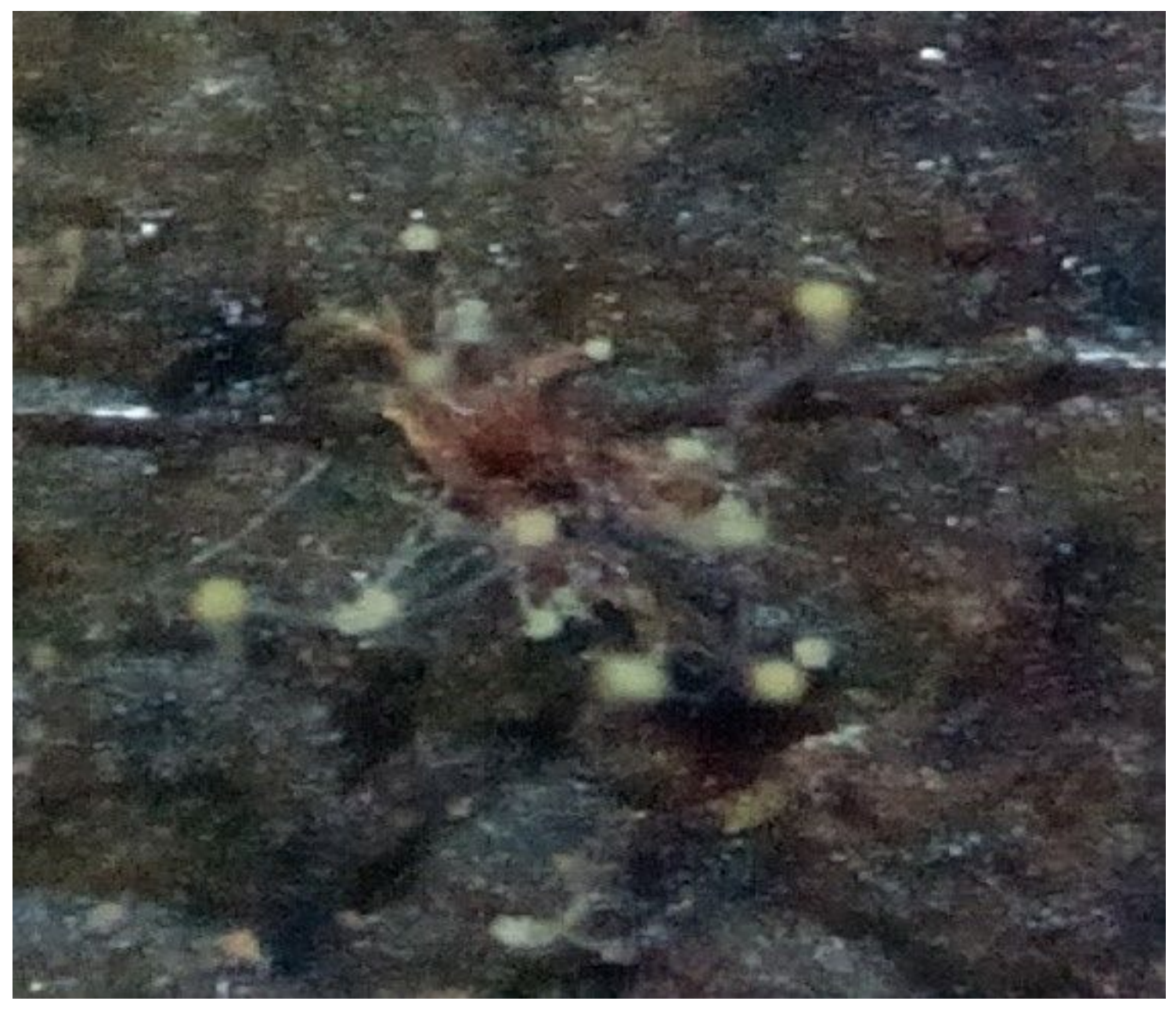

Figure 2

M. anisopliae conidia on T. urticae and kidney bean leaf 